Ethiopian Journal of Environmental Studies \& Management 10(1): 125 - 136, 2017.

ISSN:1998-0507

doi: http://dx.doi.org/10.4314/ejesm.v10i1.12

Submitted: November 08, 2016

Accepted: January 30, 2017

\title{
HEALTH IMPACT OF LEACHATES FROM ILLEGAL DUMPSITES: CASE STUDY OF KUBWA ABUJA, NIGERIA
}

*AHMED, Y.A., ADERONKE, M. AND OYEWO, S.O.

Department of Geography and Environmental, Management, University of Ilorin, Nigeria

\begin{abstract}
This study examines the perilous impact of leachate's foray on Kubwa-Abuja's environment; with the purpose to enlightening city's inhabitants from dumping refuse indiscriminately on unauthorized sites which may proactively have composite consequences on the environment and people living around the illegal dump-sites. Kubwa-Abuja area has three conspicuous illegal dumpsites which were designated as zones $A, B$, and $C$, using estimated distance apart. The three zones are residential houses within 100 meters radius; residential houses within 200 meters radius and residential houses within 300 meters radius from the dumpsites. Data for the study were obtained from both primary and secondary sources. The primary source reflect the administration of 200 questionnaires each to selected household members in the three designated zones and oral interview were conducted to random selected public members and the refuse control agencies in as to obtain information about impacts incursion of the unauthorized dumpsites in the study area. While the secondary source reveal the related literature on the work. Multiple Regression Analysis was used to test the hypotheses set. It was observed that significant differences exist in susceptibility of the populace to health related diseases and effect of leachate emanating from dumpsites on the nearby water. Policy measures are suggested on how best to curb the impact of illegal dumpsites on city environment.
\end{abstract}

Key Words: Leachate, Environment, Perilous, Dumpsites and Kubwa-Abuja

\section{Introduction}

The bungling urban growth, prominent population increase, low coordinated industrial setup and other human related activities in Nigeria cities' environment have resulted to generation of large quantity of wastes which are usually dumped indiscriminately on illegal sites, thereby contaminating surface water and affecting the quality of the environment (Adedeji et al., 2014). Many major cities in Nigeria today are changing their environmental outlook into great potentiality both in good; socio-economic as well as in political affiliations worth commendable. Upon this however, some cities in the country, still live in shadow of neatness and tidiness. Cities are said to be engine of sustainability of all development and sources of economic growth. But environmental insinuation of such development deserves to be thoroughly managed, because its effects may be illfelt, and hazardous. Such growth and 
development need to be thoroughly managed to suppress its laid-up consequences (Ahmed, 2013).

Leachate is an aqueous effluent generated as a result of rainwater percolating through wastes, as well as the inherent water content of waste themselves which serves as an important source of pollution in many environmental media around the world (Ojo, 1995). Leachate consists of undesirable material derived from the waste that it has passed through; the constituent of leachate depends on the waste it receives. A dumpsite that receives mixture of municipal, commercial and industrial wastes will have a leachate that is characterized as a water-based solution of four groups of contaminants namely; dissolved organic matter, inorganic macro components, heavy metals $(\mathrm{Pb}, \mathrm{Ni}, \mathrm{Cu}$, $\mathrm{Hg}$ ), and organic compounds (Oludare and Olayinka, 2014). The physical appearance of Leachate when it emerges from a dumpsite is either black or yellow liquid with an acidic and offensive smell. Leachate discharge has a great impact on the environment ranging from land pollution to water pollution including surface and ground water pollution. This is because leachate flows with runoff into water bodies, thereby exposing the people in the surroundings of the dumpsite to various water borne diseases like typhoid, malaria, cholera, dysentery etc. while aquatic habitats are also disrupted.

The hazard posed by leachate on water has continued to increase greatly in the World. According to the World Health Organization (2011) more than a third of the world's people lack safe water supply, it's estimated that by 2025 , more than two thirds of the global population will live in countries with serious shortage of clean water. Indiscriminate refuse disposal is found to be the major threat to water quality and has been suggested that water contamination is the leading cause of deaths and diseases. It is therefore imperative to examine the environmental impact of leachate discharge on illegal dumpsites and what potential impacts leachate possess for the people living within the vicinity of the dumpsites.

\section{Study Area}

Kubwa is one of the district areas of Abuja, the capital city of Nigeria. It lies between latitude $8.25^{\circ} \mathrm{N}$ and $9.20^{\circ} \mathrm{N}$ of the Equator and longitude $6.45^{\circ} \mathrm{E}$ and $7.39^{\circ} \mathrm{E}$ of the Greenwich Meridian (see figs.1,2 and 3). Kubwa is the largest settlement in Abuja with population of 776,298 (NPC, 2006). Abuja has a tropical climate which is characterized by wet and dry season (World Bank, 2000; Nyame, 2012). Rainfall in Abuja is majorly an orographic type, as a result of its location proximity to the windward side of the Jos plateau. Relative humidity is about $20 \%$ in the dry season and $50 \%$ in the wet season (Okunola et al., 2014). The soils of Abuja are generally shallow and sandy in nature, the high sand content makes the soil to be highly erodible and the shallow depth is a reflection of the presence of stony lower horizons (Olubunmi and Ndubusi, 2011). The vegetation type in Abuja is the Guinea Savannah, it comprises of tall grasses which are inter-spaced with scattered specie. Abuja is predominantly underlain by high grade metamorphic rock of Precambrian age (Umar, 2012).The topography is rugged and undulating with the basement rock outcropping as hills and inselbergs and the geologic formation in the area comprises of basement complex rocks that form prominent hilly physiographic features (Agunwamba, 1998).The lowest elevation of Abuja is 
found in the extreme South West with an elevation of $70 \mathrm{~m}$ above sea level. The highest elevation is found in the North East where there are many peaks over $760 \mathrm{~m}$ above sea level. Hills occur either as clusters or form long ranges. Isolated hills called inselbergs are also found in some part of the city. The dominant occupation found in Abuja consists of administrative work because majority of government ministries, headquarters and federal secretariats are located within Abuja and as a result, government agencies employ the service of civil servants in the area. Some people most especially the Gwagi's also engage in primary occupation such as farming (cultivation of crops like yam, maize, vegetables etc.) and fishing among others.

Abuja being the capital city of Nigeria has been planned to have series of waste management and control strategies for urban development. It has the Ministry of Environment and Abuja Environmental Protection Board (A.E.P.B) to manage its environments. Abuja Environmental Protection Board (A.E.P.B) was established by the Federal Capital Territory Administration (FCTA) on the $31^{\text {st }}$ of July 1989 in accordance to decree No.10, section 47 of the Federal Environmental Protection Agency of Nigeria (FEPA, 1991). Abuja has four legal dumpsites; two old dumpsites namely Gosa and Wupa dumpsites and two newly created dumpsites- Bwari and Dustse Makaranta All are to complement the others in order to ease pressure on the previously existing two dumpsites (FEPA, 1991). However, many other major illegal dumpsites apart from Kubwa and others exist around Abuja metropolis, all are in the full fledged for discussion in this work. 


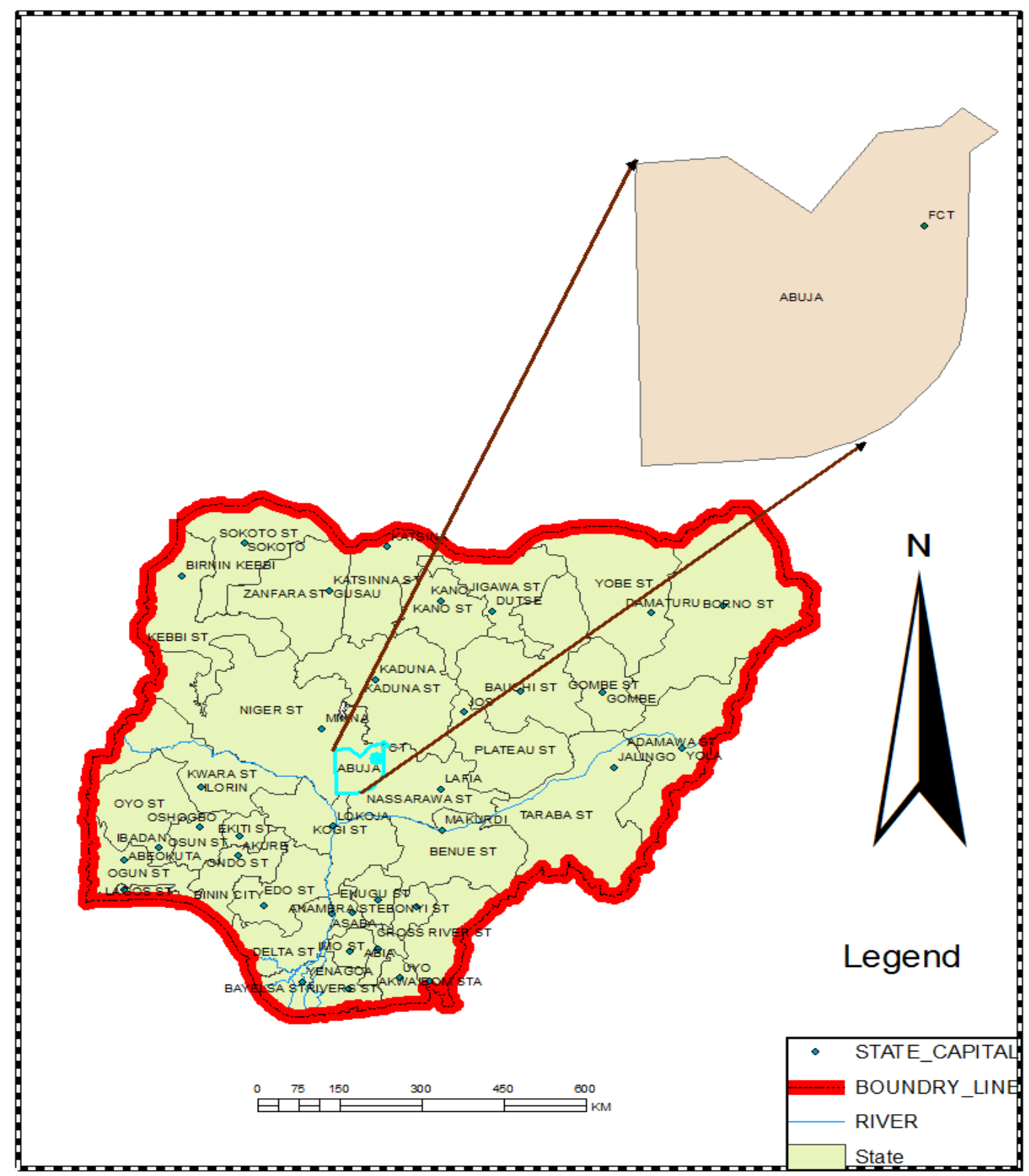

Fig 1: Map of Nigeria showing Abuja 
Ethiopian Journal of Environmental Studies and Management Vol. 10 no.12017

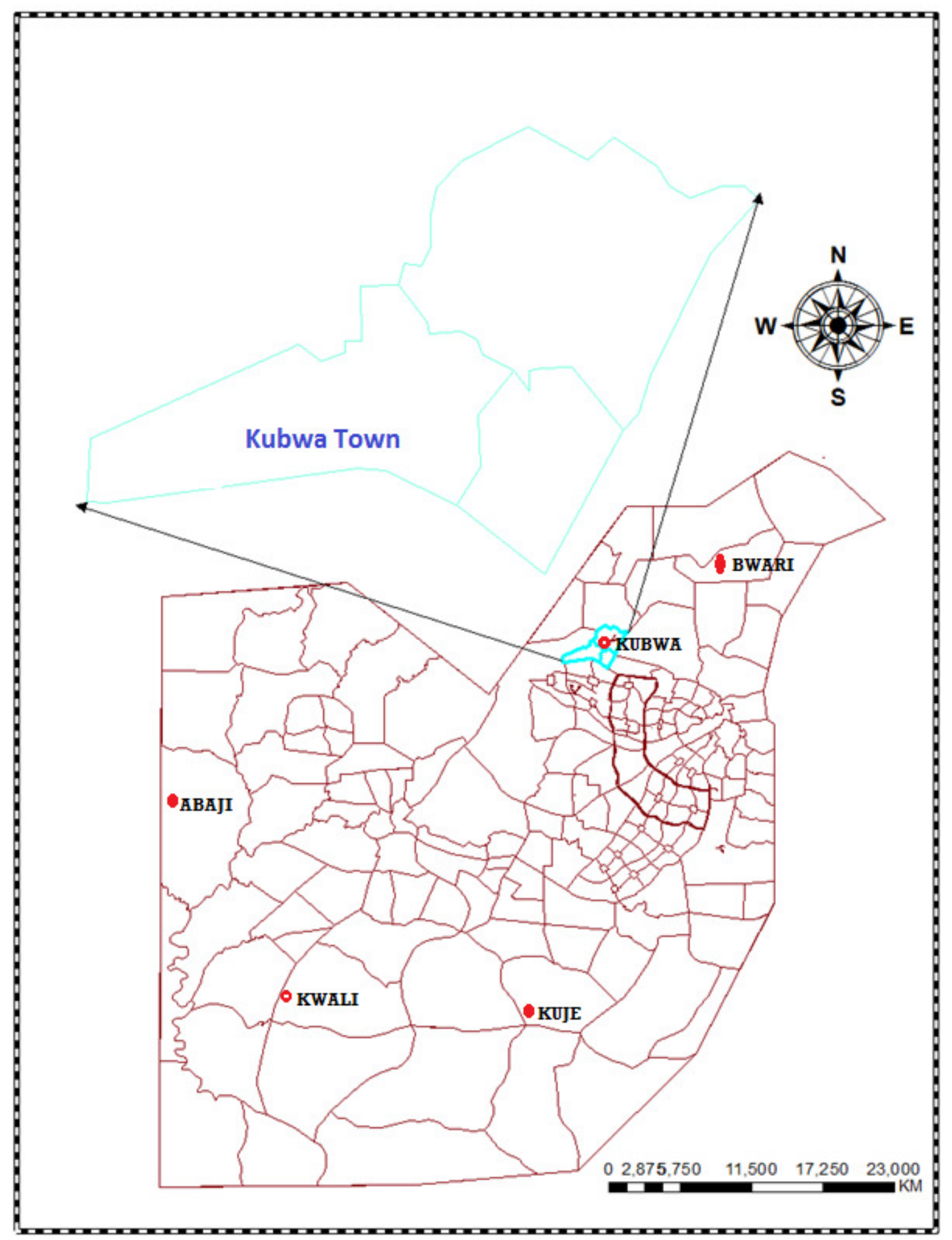

Fig 2: Map of Kubwa-Abuja showing the study area 


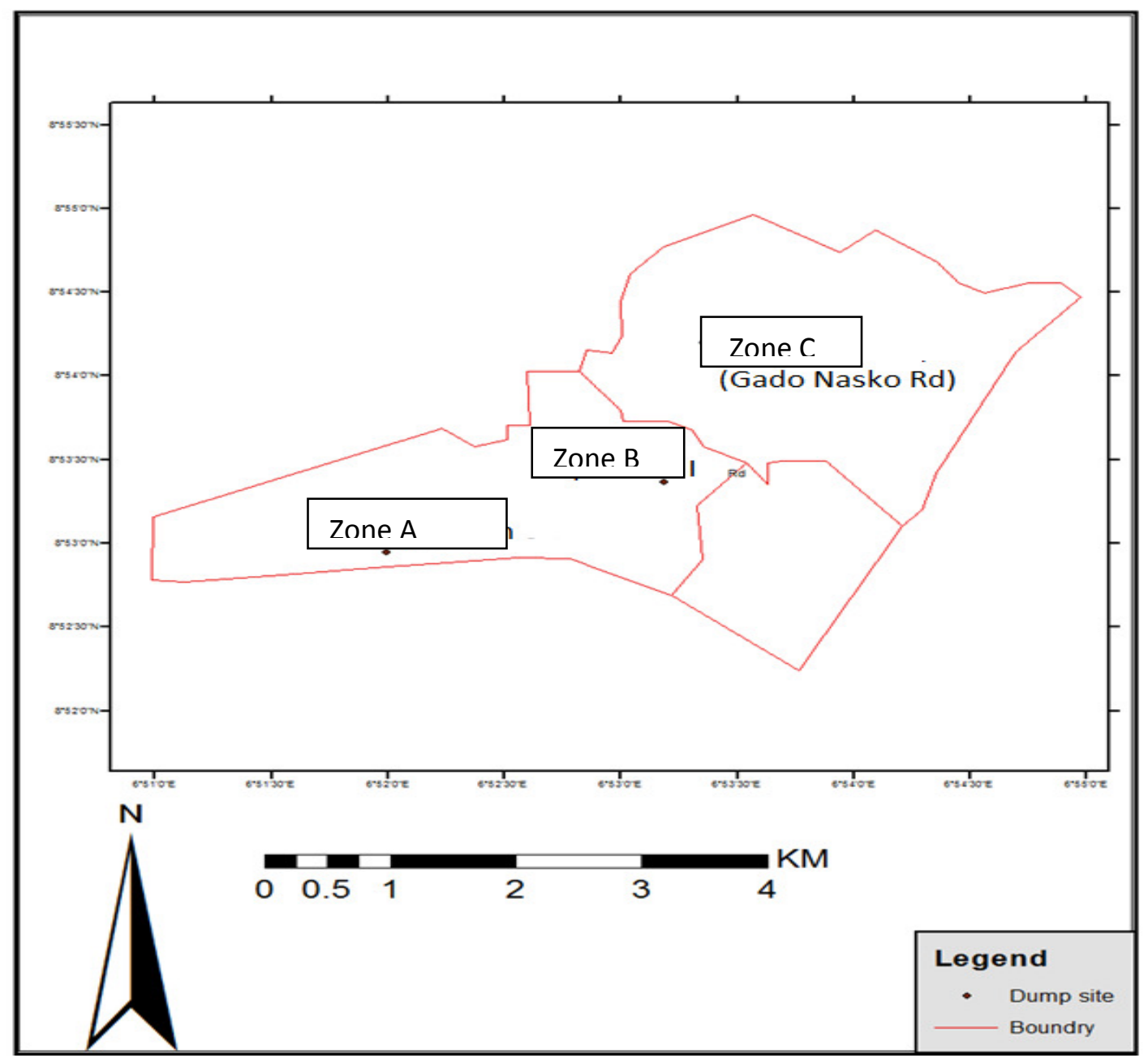

Fig 3: Map of Kubwa-Abuja showing Designated Zones

Several water borne diseases were discovered affecting people that residing in the zones of the study area, some of the diseases like; pathogens, causes and symptoms are discussed orally and in the scheduled questionnaires administered (see tables 1-2 ). Common Health cases recorded as revealed from the questionnaires response indicated one death case in Zone $\mathrm{A}$ due to snake-bite commonly associated to dangerous reptiles that lived within the heaps of refuse in the area. As revealed by the residents from Zone A, the affected person was not taken to a nearby hospital on time. Other deaths from Zone $\mathrm{C}$ were due to illness contacted as a result of contaminants from the dumpsites mostly resulted from diarrhoea and dysentery with little attention or none. 
Table 1: Leachate's Health Incidence in Kubwa-Abuja

\begin{tabular}{llllll}
\hline Zone A & $\begin{array}{l}\text { Number of } \\
\text { infected persons }\end{array}$ & $\begin{array}{l}\text { Treated at } \\
\text { Home }(\%)\end{array}$ & $\begin{array}{l}\text { Treated at } \\
\text { Hospital }(\%)\end{array}$ & $\begin{array}{l}\text { No. of death } \\
\text { Recorded }\end{array}$ & Remark \\
\hline Typhoid & 35 & $16(45.71)$ & $19(54.28)$ & - & - \\
Diarrhoea & 17 & $9(52.94)$ & $8(47.06)$ & - & - \\
Malaria & 189 & $47(24.87)$ & $142(75.13)$ & - & - \\
Dysentery & 67 & $11(16.42)$ & $56(83.58)$ & - & - \\
Snake-bite & 5 & $2(40.00)$ & $3(60.00)$ & 1 & $\begin{array}{c}\text { Lateness to attend } \\
\text { available hospital } \\
\text { caused death }\end{array}$ \\
Scorpion-bite & 28 & & & & - \\
Others & 15 & $9(32.14)$ & $19(67.86)$ & - & - \\
\hline
\end{tabular}

Table 2: Leachate's Health Incidence in Kubwa-Abuja

\begin{tabular}{lccllll}
\hline Zone B & $\begin{array}{l}\text { Number } \\
\text { Infected } \\
\text { persons }\end{array}$ & of & $\begin{array}{l}\text { Treated at } \\
\text { Home }(\%)\end{array}$ & $\begin{array}{l}\text { Treated at } \\
\text { Hospital }(\%)\end{array}$ & $\begin{array}{l}\text { No. of death } \\
\text { recorded }\end{array}$ & Remark \\
\hline Typhoid & 15 & $3(20.00)$ & $12(80.00)$ & - & - \\
Diarrhoea & 8 & $1(12.50)$ & $7(87.50)$ & - & - \\
Malaria & 76 & $23(30.26)$ & $53(69.74)$ & - & - \\
Dysentery & 90 & $40(44.44)$ & $50(55.56)$ & - & - \\
Snake-bite & - & - & - & - & - \\
Scorpio-bite & 42 & $9(21.43)$ & $33(78.57)$ & - & - \\
Others & 21 & $3(14.29)$ & $18(85.71)$ & - & - \\
\hline
\end{tabular}

\section{Method of Study}

The methods employed for this work are highlighted below: In the first place, reconnaissance visits were carried out by the researchers on different locations within Kubwa areas of Abuja for on-spot assessment. This was done in as to ascertain the locations of authorized and illegal adopted dumpsites and to update information collected from the secondary data source. The said field assessments that were carried out complement the secondary data and they include data on the selected three illegal dumpsites in Kubwa namely; Byanzhin, Phase III and Phase IV. During this fieldwork, some preliminary mapping activities were carried out to delineate the larger area covered and surveyed and were later referred as; Zone $\mathrm{A}, \mathrm{B}$ and $\mathrm{C}$ for easier understanding. The three zones covered: residential houses within 100 meters radius; residential houses within 200 meters radius and areas covered within 300 meters radius respectively (see figs.1-3). Other primary data were directly collected through the administration of 300 hundred structured questionnaires in line with the objectives of the study and this to harmonize with the on-spot assessments mentioned above. The structured questionnaires were administered to 300 household heads chosen randomly within the three delineated zones (see fig.3). Oral interviews were also conducted among the selected members of the general public such as; the target groups- individuals living within the designated areas, the government and the private agencies that controlled and managed wastes, and the 
selected Abuja Environmental Development Agency (AEDA) officers. The objective of identifying sociological perception and health impacts of dumpsites in Kubwa environs were focused in the oral interviews. Whereas, representatives from relevant departments and other health and environmental managers were not left out. Above all, three basic hypotheses were set to test if there is existence of any environmental consequence of leachate discharges from illegal dumpsites on Kubwa environs.

(a) $\mathrm{Hi}$ - Adequate waste management will reduce the impact of environmental degradation and outbreak of diseases compared to indiscriminate refuse dumping that would lead to environmental fallout.

Ho - There is no significant difference between adequate waste management and indiscriminate refuse dumping.

(b) Hi- Those who reside close to dumpsites vicinity are much more susceptible to health hazard than those leaving far from dumpsite zones.

Ho-There is no difference in the susceptibility of residents to health hazard than those reside close to or far from dumpsite zones.

Table 3: Showing the Means Variation on Health Status Base on Dumpsites and Delineated Zone

\begin{tabular}{llll}
\hline Variables & Byanzhin Dumpsites & Phase III Dumpsites & Phase IV Dumpsites \\
\hline Zone A $(100-199 \mathrm{~m})$ & 6.57 & 6.17 & 7.22 \\
Zone B $(200-299 \mathrm{~m})$ & 4.61 & 4.35 & 4.87 \\
Zone C $(300+)$ & 3.04 & 3.43 & 4.09 \\
\hline
\end{tabular}

The health mean of each delineated zones in table 3 was obtained by computing from the number of times in which the respondents fall sick as a result of contacting waterborne diseases.

\section{Data Analysis}

Many residents in the study area were affected by water borne and other diseases among residents in the zones of study. Some of the diseases were mentioned orally and from the answers provided from scheduled questionnaires administered to respondents in the zones (see tables 1, 2 and 4). Common health cases recorded indicated one death case in Zone $\mathrm{A}$ and due to snake-bite commonly associated to dangerous reptiles that lived within the heaps of refuse indiscriminately dumped in the area. As revealed by the residents from Zone A, the affected person was not taken to a nearby hospital on time. Other deaths from Zone $\mathrm{C}$ were due to illness contacted as a result of contaminants from the dumpsites mostly resulted from diarrhoea and dysentery among other contacted infirmity within the zones. For example, common health cases recorded as indicated in Zone A showed that 189 malaria cases were recorded with $24.87 \%$ persons were treated at home and $75.13 \%$ of the total were treated at health institutions( privately owned or government hospitals). While, this was followed by dysentery cases which about $83.58 \%$ and $16.4 .2 \%$ of the infected persons were treated at health institutions and at home respectively. 
In the case of Zone B, out of the total number of 252 people that were infected by different types of one disease or the other, and as a result of chemical oozed out from the refuse dumped in the unauthorized areas (in the zone), $31.3 \%$ of the total illness were treated at home and $68.7 \%$ cases were treated at health institutions. No any death record was reported among the residents of the study area within the time frame of this study. However, in the case of Zone $\mathrm{C}$ in the Kubwa-Abuja, from 389 cases of infirmity on record, it was this area that has not less than $17(4.37 \%)$ death cases due to negligence, poor diagnostic or treatment of wrong ailment and/or treatment of infected persons at homes without attended the available health institutions. In all, this zone recorded 82 cases of typhoid, 77 malaria cases, 115 dysentery infections and 56 infirmities from other related water borne diseases. Generally, 71(18.25\%) of the total cases were treated at home, while $318(81.75 \%)$ cases of infections were treated at big hospitals, cottage hospital and dispensary as the gravity of case(s) reflected. The hypotheses tested also indicate more impacts on health implications, environmental degradation, virtual pollutions, disruption of natural eco-systems, rodents and pests attacks on Kubwa community. This was further tested using Multiple Regression Statistical Analysis (see table 5). The Multiple Regression Analysis shows a remarkable positive correlation in zone $\mathrm{AC}$ than the rest of other zones. More people used the nearest dumpsites closer to their living area with little attention paid to the control of the sites, leading to a lot of health implications as reflected above.

\section{Results ad Discussion}

From all indications, majority of the infected persons in the study area experienced one form of disease or the other except that the degree at which they are affected by malaria and dysentery and diarrhoea are higher than from other infirmities. Based on observed means, the error term is Mean Square (Error) = .212

From table 6 , it will be observed that there is statistical difference between each of the delineated zones, (1) Zone $\mathrm{A}$ and Zone B, (2) Zone A and Zone C (3) Zone $\mathrm{B}$ and Zone $\mathrm{C}$. from the results we can see that there is a statistically significant difference between all three delineated Zones Level $(p=0.05)$ The result shows that Zone A inhabitants are significantly more affected by health diseases related to proximity to dumpsites than inhabitants of Zone $\mathrm{B}$ at level of $(\mathrm{P}=.04)$, Zone $\mathrm{A}$ and Zone $\mathrm{C} \quad(\mathrm{p}=0 . .00)$ while there is no differences between Zone B and Zone C level $(\mathrm{p}=.063)$

Therefore we accept both $\mathrm{Hi}$ hypotheses because proximity to dumpsite is a key factor in experiencing impacts of leachate which is water borne diseases:

a) $\mathrm{Hi}$ - Adequate waste management will reduce the outbreak of disease compared to indiscriminate refuse dumping.

b) Hi- Those who reside close to dumpsites are much more susceptible to water borne diseases than those leaving far from dumpsites. 
Table 4: Leachate's Health Incidence in Kubwa-Abuja

\begin{tabular}{|c|c|c|c|c|c|}
\hline Zone $\mathrm{C}$ & $\begin{array}{l}\text { Number of } \\
\text { infected persons }\end{array}$ & $\begin{array}{l}\text { Treated at } \\
\text { Home (\%) }\end{array}$ & $\begin{array}{l}\text { Treated at } \\
\text { Hospital } \\
(\%)\end{array}$ & $\begin{array}{l}\text { No. of } \\
\text { death } \\
\text { Recorded }\end{array}$ & Remark \\
\hline Typhoid & 82 & $12(14.63)$ & $70(85.37)$ & 14 & $\begin{array}{l}\text { Negligence, wrong } \\
\text { infection/ treatment caused } \\
\text { death }\end{array}$ \\
\hline Diarrhoea & 45 & $4(8.89)$ & 41(91.11) & 02 & $\begin{array}{l}\text { Lateness to attend hospital } \\
\text { Caused death }\end{array}$ \\
\hline Malaria & 77 & 19 & $58(75.32)$ & & \\
\hline Dysentery & 115 & $10(8.70)$ & $105(91.30)$ & 01 & $\begin{array}{l}\text { Treatment of infections at } \\
\text { Home caused death }\end{array}$ \\
\hline Snake & & & & & - \\
\hline Scorpion-bite & 14 & $7(50.00)$ & $7(50.00)$ & - & - \\
\hline Others & 56 & 19(33.93) & $37(66.07)$ & & \\
\hline
\end{tabular}

Table 5: Multiple Regression Analysis Resulting from Closeness to Dumpsites and Health Status

\begin{tabular}{ccccccc}
\hline $\begin{array}{r}(\mathrm{S}) \\
\text { Zone }\end{array}$ & $\begin{array}{c}(\mathrm{T}) \\
\text { Zone }\end{array}$ & Mean Difference (S-T) & Std. Error & Sig. level & \multicolumn{2}{c}{$95 \%$ Confidence Interval } \\
\hline & & & & & Lower bound & Upper bound \\
$\mathrm{A}$ & $\mathrm{B}$ & $2.0500^{*}$ & .37579 & .004 & .8970 & 3.2030 \\
& $\mathrm{C}$ & $3.1333^{*}$ & .37579 & .000 & 1.9803 & 4.2863 \\
$\mathrm{~B}$ & $\mathrm{~A}$ & $-2.0500^{*}$ & .37579 & .004 & -3.2030 & -.8970 \\
& $\mathrm{C}$ & 1.0833 & .37579 & .063 & -.0697 & 2.2363 \\
$\mathrm{C}$ & $\mathrm{A}$ & $-3.1333^{*}$ & .37579 & .000 & -4.2863 & -1.9803 \\
& $\mathrm{~B}$ & -1.0833 & .37579 & .063 & -2.2363 & .0697 \\
\hline
\end{tabular}

* The mean difference is significant at the .05 level.

Environmental Impact Assessment of Leachate in Kubwa, Abuja

Kubwa inhabitants were in no doubt exposed to various consequences attributed to impact of mismanaged dumpsites like most urban centres in Nigeria. Apart from leachate that flow into Kubwa streams, local waste collectors known as Babanbolas (waste scavengers in exchange for money) emptied there collected waste in nearby streams (Chijioke, 2014). Other implications are;

Despite government efforts to alleviate illegal dumpsite in Abuja metropolis, the number of illegal dumpsites keeping on increased and this is as a result of the following;
- Lack of moral ethics towards environment education which most people are yet to learn due to their nonchalant attitudes towards environmental management.

- Increasing migrants into Abuja city from all over the country also increasing the quantity of waste generated, thus making it more difficult to make adequate provision to commensurate with dumpsites

- Insufficient manpower to manage wastes as different government have different policies for waste control and management

- Poor Funding on the part of Waste Management Agency i.e in places 
where people pay to dispose waste makes it a challenge for the financially less privileged to comply with such policies.

- Weak enforcement agency mostly in developing countries also makes people to be careless with waste management policies

- Inadequate government facilities and infrastructure to control waste i.e. government plan for legal dumpsites are only in few in cities like Abuja, where there are old vehicles, unserviceable Ro-ro vehicles and other facilities are not intact or are badly managed.

\section{Conclusion}

From all indications, it could be seen that dumping of refuse on illegal or unauthorized sites is tantamount to act of untidiness, uncare free-attitudes that are associated with uncooperative behaviours to constituted authority. This not constitutes to menace to environmental degradation but also to real danger and threat to socio-economic and political development of the nation.This paper has placed a substantial hope and priority on improvement of waste management strategies in the country in order to mitigate illegal dump of watses that may lead to leachate actions on the environment.Waste could be asset and benefit to all if well monitored.Therefore, both the private companies and individuals could be encouraged to source for new wealth from refuse dumped in legal sites/areas and take advantage of this by not allow waste to degenerate into leachate before it is well managed as it is being done in the developed world. Finally, the work has also demonstrated a research effort on upgrading waste control and management in order to improve our health conditions away from any infirmity in Kubwa-Abuja and Nigeria as a whole. The bulk of control of waste and its management is however left to the government but above all, every community,individuals, also both private and public organization have unique roles to play in as to improve the quality of our environment in the country.

\section{Recommendations}

Wellbeing is one of the liveable characteristics of a developed nation; combating illegal waste dumpsites will go a long way to preventing or eradicating water borne diseases that emanate from contagious leachate from the waste dumpsites in this country. Hence, the followings are solutions propounded by the respondents for a better improvement of people living in the study area:

- Water purification method such as sieving, boiling before use is also advocated for.

- Increase in enlighten of the populace about benefits and consequences of hygienic and in hygienic environment respectively.

- Adequate low or zero cost transport facility should be provided by government for conveying waste to the legal dumpsites.

- Sophisticated adoptions of waste resource management which include reduce, reuse and recycle.

- Community should work hand in hand with government to maintain and complement government efforts on waste management.

- NGOs should also complement the effort of government in managing waste 
- Private industries should invest in waste management.

\section{References}

Adedeji, O.H., Oludare, H. and Olayinka, O.O. (2014). 'Concentrations of Heavy Metals in Dumpsite Leachate and effects on Adjacent Stream in Ajakanga', Ibadan Nigeria. Journal of Applied Sciences in Environmental Sanitation, 9(2): 113.

Ahmed, Y. A. (2013). "Potential Impacts of Climate Change on Waste Management in Ilorin City, Nigeria. International Journal of Science and Technology 2 (1), 45-63.Bahir Dar, University Ethiopia.

Agunwamba, J.C. (1998). "Solid Waste Management in Nigeria: problems and issues" Environmental Management, 6(22): 849-856.

Chijioke, O. (2014).'Dumping of Refuses into Kubwa Streams', the Observer Newspaper, Abuja, Nigeria.

FEPA, (1991). Guidelines and Standards for Environmental Pollution Control in Nigeria.

National Population Commission (NPC, 2006), Abuja, Nigeria

Nyema, F.K. (2012). 'Environmental Implications of the Discharge of Municipal Landfill Leachate into the Densu River and surrounding Ramsar Wetland on the Accra Metropolis', Proceedings on Health. AccraGhana.

Ojo, O. (1995). 'Assessing and Managing Health Risks from Drinking Water Contamination: Approaches and
Applications' (Proceedings of the Rome Symposium).

Okunola, I.A., Amadi, A.N., Idris-Nda, Agbasi, K, Kolawole, L.L. (2014). 'Assessment of Water Quality of Gurara Water Transfer from Gurara Dam to Lower Usuma Dam for Abuja Water Supply, FCT, Nigeria'. American Journal of Water Resources, 3(4): 74-80. Available online at http://pubs.com

Olubunmi, A.N. and Ndubuisi, A. (2011). 'Impacts of Industrial Effluent and Dumpsite Leachate Discharges on the Quality of Groundwater in Oyo state', Nigeria: Journal of Biodiversity and Environmental Sciences (JBES), 3(1): 13-18.

Oludare, H.A. and Olayinka, O.O. (2014). 'Concentration of Heavy Metals in Dumpsites Leachate and Effects on Adjacent Stream in Ajakanga, Ibadan, Nigeria'. Journals of Applied Sciences in Environmental Sanitations, 113-122.

Umar, A.M., Onimisi, M.Y. and Jonah, S.A. (2012). 'Measurement of Natural Radioactivity in Soil, Vegetation, and Water in the Industrial District of the FCT', British Journal of Applied Sciences Technology, 2(3): 266-274.

World Health Organization (WHO) (2011). Costs and Benefits of Water and Sanitation Improvements at the Global Level.

http// 